\title{
Cholesterol Derivatives as Promising Anticancer Agents in Glioblastoma Metabolic Therapy
}

\author{
Khouloud Sassi ${ }^{1,2} \bullet$ Thomas Nury ${ }^{1}$ - Mohammad Samadi ${ }^{3} \bullet$ \\ Fatma Ben-Aissa Fennira ${ }^{2} \bullet$ Anne Vejux$^{1} \bullet$ Gérard Lizard $^{1}$ \\ ${ }^{1}$ University Bourgogne Franche-Comté, Team 'Biochemistry of the Peroxisome, \\ Inflammation and Lipid Metabolism' EA 7270 / Inserm, Dijon, France; \\ ${ }^{2}$ University Tunis El Manar, Laboratory of Onco-Hematology (LR05ES05), \\ Faculty of Medicine, Tunis, Tunisia; ${ }^{3}$ University Lorraine, LCPMC-A2, ICPM, \\ Department of Chemistry, Metz Technopôle, Metz, France
}

Author for correspondence: Gérard Lizard, Faculté des Sciences Gabriel, Laboratoire Bio-peroxIL/EA7270, 6 boulevard Gabriel, 21000 Dijon, France. Email: gerard.lizard@u-bourgogne.fr

Doi: https://doi.org/10.36255/exonpublications.gliomas.2021.chapter6

\begin{abstract}
Malignant brain tumors are among the most devastating types of cancer. Glioblastoma is the most common and serious form of brain cancer. Most glioblastomas are surgically unresectable and are typically diagnosed at an advanced stage. The high level of resistance to chemotherapy, radiotherapy and immunotherapy makes glioblastoma one of the most difficult cancers to treat. In brain tumors, the challenges of targeted therapy also include the blood-brain barrier, which often contributes to treatment failure. Therefore, developments of new treatment strategies are required. Metabolic treatments could be an alternative to conventional therapies. Metabolic approaches aim at suppressing glioblastoma tumorigenicity leading to glioblastoma cell death. Since cholesterol metabolism is deregulated in these tumors, this is a promising potential target for therapy. As glioblastoma cells draw on cholesterol from the central nervous system to survive,
\end{abstract}

In: Gliomas. Debinski W (Editor). Exon Publications, Brisbane, Australia. ISBN: 978-0-6450017-4-7; Doi: https://doi.org/10.36255/exonpublications.gliomas.2021

Copyright: The Authors.

License: This open access article is licenced under Creative Commons Attribution-NonCommercial 4.0 International (CC BY-NC 4.0) https://creativecommons.org/licenses/by-nc/4.0/ 
their growth is theoretically unlimited. Targeting the metabolism of cholesterol by different strategies using, among others, targets of LXRs (Liver X Receptors) or toxic cholesterol analogues could potentially oppose the growth of glial tumors. This chapter discusses the potential of targeting cholesterol metabolism using cholesterol derivatives as a pharmacological alternative to current therapeutic strategy.

Keywords: cancer metabolic therapy; cholesterol derivatives; cholesterol metabolism; glioblastoma; oxysterols

\section{INTRODUCTION}

Most of central nervous system (CNS) cancers are found in the brain while others develop in the meninges, spinal cord, and cranial nerves (1). The origin and location of brain tumors determine their type. Primary brain cancers originate in the brain which is also a frequent site for secondary or metastatic tumors. Gliomas are the most common primary tumor of the CNS (2). According to the World Health Organization (WHO), gliomas are traditionally classified based on the cell type of origin: astrocytic, oligodendroglial, oligoastrocytic, or ependymal tumors $(3,4)$. The current classification system is a grading system that grades tumors from grade I (benign) to IV (highly malignant) based on increasing cellular density, nuclear atypias, mitosis, vascular proliferation and necrosis (5). Glioblastoma is the most aggressive diffuse glioma of astrocytic lineage and is considered a grade IV glioma (4), making up 54\% of all gliomas and $16 \%$ of all primary brain tumors (5). Glioblastoma is characterized by an aberrant metabolism which has important roles in carcinogenesis, metastasis, drug resistance, and cancer stem cells. Cancer cells adapt their metabolism in response to signals from the microenvironment and proliferation (6). Therefore, overcoming metabolic alterations is an important goal of modern cancer therapeutics.

\section{CANCER METABOLISM}

Aberrant metabolism is a major feature of cancer that directly affects tumor signal transduction pathways and cellular reactions. The metabolic heterogeneity and plasticity of cancers results from genetic heterogeneity and cancer microenvironment. Oncogenic signal pathways including Hippo, PI3K-AKT/mTOR, Myc, p53 and LKBl-AMPK play an important role in the regulation of cancer metabolism (7). Hence, overcoming metabolic plasticity constitutes a therapeutic challenge. Cancer cells modify their metabolic pathways, maximizing the expression and the efficiency of metabolic enzymes activities to meet their increased needs and to overcome cancer microenvironment which induces chronic nutrient deficiency and oxygen concentrations reduction $(8,9)$. Respiratory mechanisms in cancer cells are still under investigation. Warburg effect states that respiratory mechanisms are damaged especially in the mitochondria and that cancer cells obtain ATP through glycolysis instead of oxidative phosphorylation (10), while other 
data argue that the cancer cells produce energy using oxidative phosphorylation and their mitochondria is intact $(11,12)$. As a result of glycolysis and oxidative phosphorylation, glutamine becomes the main source of NADH and FADH2 giving rise to upregulated glutaminolysis in cancer cells (13). Fatty acids do not merely have roles as structural components but are also vital for cell response and cancer cell proliferation. Fatty acid synthesis is upregulated in tumors (14). Cancer cells compensate for fatty acid synthesis by up-regulating external lipid absorption instead of using de novo fatty acid synthesis because fatty acid synthesis is an oxygen-consuming process $(15,16)$. This upregulation overcomes the metabolic barriers that restrict the synthesis of metabolites (7). Reactive oxygen species (ROS) have been spotted in practically all cancers, where they influence cancer microenvironment and also promote many aspects of cancer development. Their contribution to carcinogenesis is still debatable and is evidently highly complex (17). Therefore, understanding the cellular metabolism that oversees ROSrelated signaling will offer appreciated visions to target cancer cells. Aberrant cancer metabolism including aerobic glycolysis, increased glutamine, and fatty acid anabolic metabolism, are not simply outcomes of aberrant signal pathways, but potentially contribute to cancer cell proliferation, metastasis and drug resistance (7). The metabolic therapy involves the bypass of cancer metabolism. It may affect sensitivity of the cancer cells to anticancer drugs and may allow them to avoid the non-specific cytotoxicity of these drugs and overcome drug resistance. This treatment approach avoids metabolic plasticity, which is the capacity of cells to adapt their metabolic status to their specific needs (18). Therefore, understanding cancer metabolism and identification of new drugs targeting it may yield new therapeutic opportunities. However, metabolic heterogeneity and plasticity make this approach difficult. One highly heterogeneous cancer for which current therapies utterly fail is the deadly brain cancer glioblastoma.

\section{GLIOBLASTOMA FEATURES}

Glioblastoma is the most common and lethal primary brain cancer that expose an implacable malignant progression characterized by expanded invasion throughout the brain, resistance to therapeutic strategies, devastation of normal brain tissue, and death (7).

\section{Epidemiology of glioblastoma}

According to the Global Burden of Disease Study in 2016, at the global level, there were 330,000 cases of CNS cancer, with an age-standardized incidence rate of 4.63 per 100,000 person-years and with an age-standardized death rate of 3.24 per 100,000 person-years (1). Glioblastoma, the most common primary brain cancer of glial origin, is almost universally fatal with a median age of 64 years (19). Incidence of CNS cancers peaks in early childhood ( $<5$ years of age) and increases after 15 years of age, with no difference in incidence rates by sex during childhood, but a diverging incidence between sexes with increasing age, leading to 1.6 times higher incidence in men than women (20), though this difference was not considered significant (1). 


\section{Risk factors for glioblastoma}

Few known risk factors are associated with CNS cancers; the only positive association being with ionizing radiation (for example, previous therapeutic irradiation) $(21,22)$. Various genetic syndromes and associated low frequency alleles are associated with increased risk of CNS cancer, but these account for only a minute fraction of total cases $(23,24)$. Glioblastoma has been associated with the viruses SV40 (25), HHV-6 $(26,27)$, and cytomegalovirus (28). Uncommon risk factors have been considered, including smoking and pesticide exposure (29).

\section{Antigenic and genetic characteristics of glioblastoma}

The characterization of molecular alterations in glioblastoma could contribute to optimal therapeutic strategies. Various prognostic markers have been identified in glioblastoma, including methylation status of the gene promoter for $\mathrm{O}^{6}$-methylguanine-DNA methyltransferase (MGMT), isocitrate dehydrogenase enzyme 1/2 (IDH1/2) mutation, epidermal growth factor receptor (EGFR) overexpression and amplification, glioma-CpG island methylator phenotype (G-CIMP), tumor protein 53 (TP53) mutation and genetic losses of chromosomes (30). Two models of progression have been proposed based on the molecular alterations in glioblastoma: primary (or de novo) glioblastoma and secondary glioblastoma. Primary de novo glioblastomas come from astrocytes or precursor/stem cells that have baseline mutations (31). Primary glioblastomas are frequently found to overexpress EGFR, and less frequently show mouse double minute 2 (MDM2) amplification, high frequency of telomerase reverse transcriptase (hTERT) promoter and p16 deletions, loss of heterozygosity on 10q, phosphatase and tensin homolog gene (PTEN) mutations while TP53 mutation is infrequent $(5,30,31)$. Secondary glioblastoma develops from a pre-existing low-grade glioma. They are characterized by TP53 mutation and alpha thalassemia X-linked mental retardation syndrome (ATR-X) $(3,30)$. Moreover, in addition to these mutations, they may present with the same molecular alterations as de novo glioblastoma. Many other genetic alterations have been described in glioblastoma, and the majority are found in two pathways: the retinoblastoma protein (RB), and the phosphoinositide 3-kinase/ protein kinase B (PI3K/AKT) (32). Glioblastoma has alterations in $68-78 \%$ and $88 \%$ of these pathways, respectively (33). Glioblastoma-O is a rare subtype of glioblastoma with an oligodendroglioma component. It has longer survival when compared to other glioblastomas $(30,34)$. According to the 2016 WHO classification, glioblastoma is classified based on the status of IDH mutation into three groups: glioblastoma IDH-wild type, which represents about $90 \%$ of glioblastomas (including giant cell glioblastoma, gliosarcoma, and epithelioid glioblastoma); glioblastoma IDH-mutant, which represents 10\%; and glioblastoma NOS (glioblastoma IDH-Not Otherwise Specified), in cases where IDH status was not sought or is not possible to confirm) $(4,35,36)$. The classification of gliomas $(3,4,37)$ is summarized in Figure 1.

\section{Glioblastoma pathogenesis}

Glioblastoma is generally located in the supratentorial region and rapidly infiltrates the brain parenchyma, sometimes becoming very large before producing 


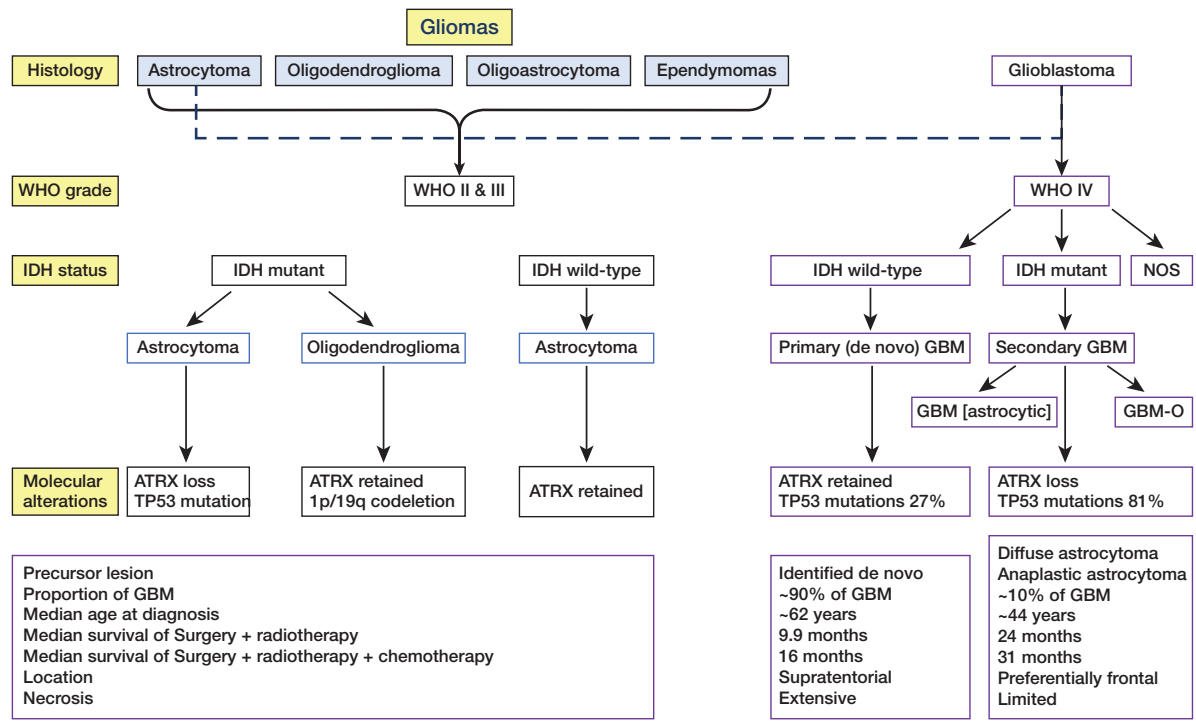

Figure 1. Classification of gliomas. Classification based on antigenic and genetic characteristics, and according to World Health Organization $(3,4,37)$.

symptoms (31). Metastases of glioblastoma beyond the CNS are extremely rare (35). Glioblastoma is characterized by the presence of hyperplastic blood vessels that present with disrupted morphology and functionality (38), with small areas of necrotic tissue surrounded by anaplastic cells. The increased hypoxia within glioblastoma leads to cancer progression by promoting processes such as immunosuppression $(38,39)$. The invasive nature of glioblastoma may be explained by: (i) the upregulation of ion channels with gene alterations (40); (ii) the oncometabolite D2-hydroxyglutarate (D-2-HG) that accumulates in the tumor cell that modifies the tumor epigenome (hypermethylation of histones and DNA) and promotes tumor initiation and progression (41); and (iii) the behavior of IDH1-mutated glioblastoma cells that invade into healthy parts of the brain where glutamate concentrations excreted by healthy astrocytes are higher (42). The invasive nature of glioblastoma, with its cellular properties similar to progenitor cells, make complete removal of glioblastoma by surgery difficult, and this could be the possible cause of resistance to conventional treatments (43).

\section{METABOLISM IN GLIOBLASTOMA}

Abnormal metabolism is an emerging feature of glioblastoma with alterations to glycolysis, oxidative phosphorylation, the pentose phosphate pathway, amino acid metabolism as well as lipid oxidation and synthesis (6). Lipid metabolism pertinent to cancer is an actionable anticancer target. De novo lipid synthesis can feed proliferating tumor cells with phospholipid components $(44,45)$. Furthermore, the upregulation of mitochondrial $\beta$-oxidation can favor cancer cell 
energetics and redox homeostasis (46). Lipid-derived messengers have also an important role in the regulation of major signaling pathways and the coordination of immunosuppressive mechanisms $(47,48)$. Thus, lipid metabolism involves a variety of oncogenic processes including carcinogenesis, metastases, and drug resistance (49-51).

\section{Cholesterol metabolism in glioblastoma}

Understanding the role of cholesterol metabolism and transport in glioblastoma cells and the underlying mechanisms of cholesterol-related drug resistance could lead to the development of more effective, targeted therapies for glioblastoma. The cholesterol pathway has emerged as a potential target for glioblastoma amenable to targeted pharmacologic treatment (52). Brain cholesterol represents $20-25 \%$ of total body cholesterol (53). However, peripheral and CNS cholesterol metabolism are regulated independently. The dynamics of the brain cholesterol pool and its metabolism is distinct from other organs due to the inability of peripheral cholesterol to cross the blood-brain barrier (54). Peripheral cholesterol depends on the balance between dietary intake and hepatic synthesis and degradation, whereas in the CNS, cholesterol is synthetized de novo by astrocytes and delivered to neurons as well as to glioblastoma cells $(55,56)$. Cholesterol provided by the astrocytes is a crucial step for growth and survival for glioblastoma cells (54). The cholesterol produced and secreted by astrocytes is supplied to the glioblastoma cells by apolipoprotein E (Apo-E). Oxysterols and other cholesterol derivatives produced in neurons following cholesterol uptake and metabolism can be physiological agonists for liver X receptors $\alpha / \beta$ (LXR) (52). Oxysterols inhibit cholesterol synthesis and enhance its export by activating LXRs $(57,58)$. Activation of LXR results in its dimerization with retinoid X receptor (RXR), favoring cholesterol efflux through sterol transporters such as ATP-binding cassette Al (ABCAl) which is the main exporter of cholesterol bound to Apo-E, and the suppression of cholesterol uptake through MYLIP also known as IDOL (inducible degrader of the LDL receptor) $(54,59,60)$. The E3 ligase IDOL is transcriptionally up-regulated by LXR/RXR in response to an increase in intracellular cholesterol (61). IDOL targets the lowdensity lipoprotein receptor (LDLR) for degradation (60). The LXR-IDOL-LDLR mechanism results in a decrease in cholesterol uptake, thereby regulating the level of intracellular cholesterol (54) (Figure 2). In glioblastoma cells, these cholesterol regulatory and surveillance mechanisms occurring in normal glial and nervous cells are disrupted $(52,54)$.

\section{CURRENT GLIOBLASTOMA THERAPIES}

Patients with CNS cancer often present with a spectrum of non-specific symptoms. There is no screening test available for CNS cancer that allows early and consistent detection (62). Because of the invasive nature of glioblastoma, the entire tumor cannot be removed surgically (63). Optimal treatment combines biopsy or aggressive surgical resection with postoperative radiation and chemotherapy (64). Despite optimal treatment, glioblastoma usually recurs. Only countries with advanced health care systems can provide highly specialized radiotherapy 


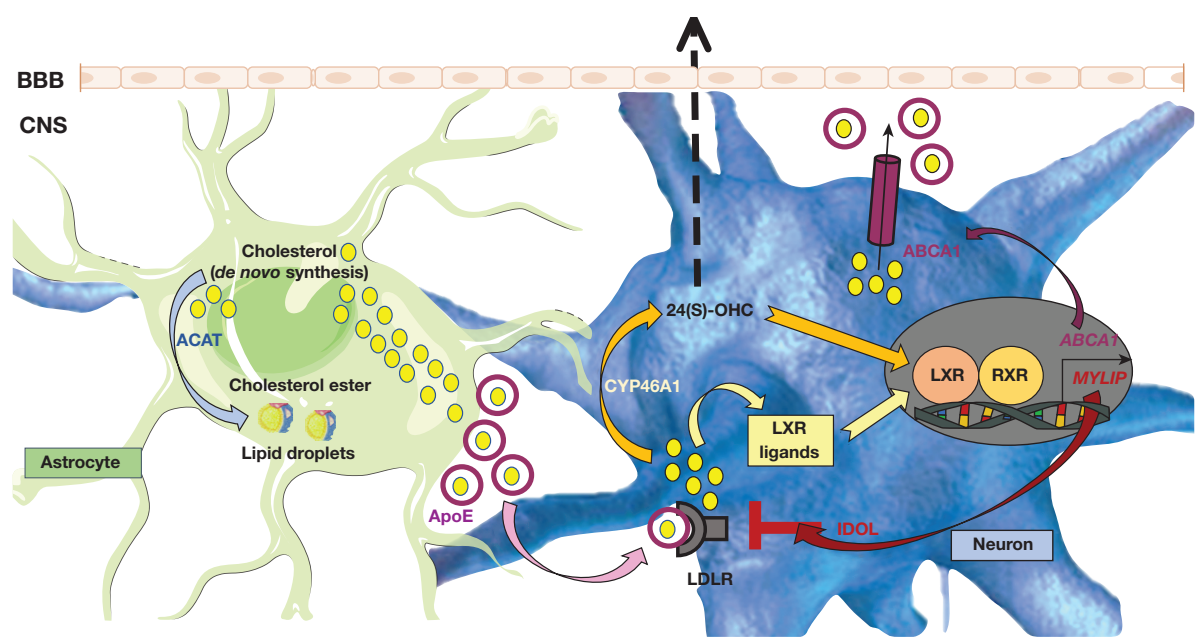

Figure 2. Regulation of cholesterol metabolism in brain neurons. Peripheral and CNS cholesterol metabolism are regulated independently. In the brain, the cholesterol produced de novo and secreted by the astrocytes is provided by Apo-E to neurons. Endogenous LXR ligands are oxysterols and other cholesterol derivatives produced in neurons following cholesterol uptake and metabolism. The main sterol transporter ABCA1 and the E3 ligase IDOL are transcriptionally up-regulated by LXR/RXR in response to an increase in intracellular cholesterol, resulting in inhibition of the expression of LDLR and in a decrease in cholesterol uptake, thereby lowering the level of intracellular cholesterol. In GBM cells, these mechanisms are disturbed. The GBM cells are unable to produce sufficient endogenous LXR ligands, especially oxysterols, thus promoting exogenous cholesterol uptake and intracellular accumulation of cholesterol which contributes to cell proliferation $(52,54)$. BBB, blood brain barrier; CNS, central nervous system.

and neuro-oncology services (65). Glioblastoma is one of the hardest to treat cancer due to its high level of resistance to conventional therapies, without forgetting the contribution of the blood-brain barrier to treatment failure (66).

Glioblastoma is diagnosed at an advanced stage and has a low survival rate of 12 to 15 months on average, with fewer than $3-7 \%$ of people surviving longer than five years (67) and without treatment, survival is typically around three months (68). Radiation and temozolomide (TMZ) chemotherapy are used after surgery to destroy what was unable to be removed surgically, and recurring tumors. TMZ is an alkylating agent; TMZ is a triazene derivative, which undergoes rapid chemical conversion at physiological $\mathrm{pH}$ to the active monomethyl triazenoimidazole carboxamide (MTIC). Glioblastomas are well known to contain areas of tissue with hypoxia, which are highly resistant to radiation. New research approaches are looking into the use of an oxygen diffusion-enhancing compound, trans sodium crocetinate (TSC), as radiosensitizer (69). Currently, chemoradiotherapy gives the best overall survival, but is associated with a greater risk of adverse events than radiotherapy alone (70). TMZ seems to work by sensitizing tumor cells to radiation, and appears more effective for tumors with MGMT promoter methylation (71). Glioblastoma therapeutic failure including immunotherapy has been attributed, among others, to its intrinsic heterogeneity and to the immune microenvironment which is considered as a major obstacle to generating 
an effective antitumor immune response $(72,73)$. Therefore, developments of new treatments are required. Metabolic treatment could be an alternative to conventional therapies.

\section{THERAPIES TARGETING CHOLESTEROL METABOLISM}

Cancer arises by mutations within oncogenes and tumor suppressor genes. These genetic mutations regulate the expression and activity of several proteins involved in the control of cell growth including metabolic enzymes which are considered attractive drug targets (7). Antimetabolites which are small molecules that inhibit the activity of enzymes involved in nucleotide base synthesis, are among metabolism-targeting drugs that have had clinical success (74). Though, nucleotide metabolism is only one of many metabolic dependencies altered to favor carcinogenesis (74). Because cholesterol metabolism involves in glioblastoma cells growth, the cholesterol pathway has emerged as a potential target for glioblastoma therapy. There are several approaches involving cholesterol metabolism known in the glioblastoma field, all of which have the same goal: the depletion of intracellular cholesterol leading to cell death.

\section{Liver X Receptors (LXR)-E3 ligase IDOL-Low-density lipoprotein receptor (LDLR)}

The LXR-IDOL-LDLR axis is a targetable pathway in glioblastoma (75). The LXR non-steroidal agonists GW3965 and LXR-623 up-regulate the expression of E3 ubiquitin ligase IDOL, which results in reduced LDLR levels. They also upregulate the expression of the cholesterol transporter gene ABCAl, which then induces substantial apoptosis via activation of the LXR $\beta$ isoform $(54,75)$. With archazolid B, the expression of LDLR is upregulated, leading to an increase in extracellular cholesterol uptake. This drug hampers the action of V-ATPase due to a proton transport defect. This leads to associated increases in lysosomal $\mathrm{pH}$, thereby preventing cholesterol recycling (76). The build-up of cholesterol within intracellular organelles makes it effectively unavailable for use by glioblastoma cells.

\section{RNA-binding proteins (RBPs)}

RNA-binding proteins (RBPs) have important roles in human biology. It has been reported that metabolic enzymes were identified as RBPs and participate in varied metabolic pathways including lipid metabolism (77). RBPs of glioblastoma are therefore another potential target. The expression and function of RNA binding proteins Fragile X-Related (FXR1) could be of interest in glioblastoma therapy. Downregulation of FXR1 or MIR17HG, also known as miR-17-92 which is the host gene for the miR-17-92a-1 gene cluster at 13q31 (78), results in inhibition of glioblastoma cells progression. The smallest tumor volumes and the longest survivals of nude mice in vivo were obtained with FXR1 knockdown combined with inhibition of MIR17HG (79). 


\section{Statins}

It is also suggested that statins could be effective in preventing drug resistance in glioblastoma. The role of intracellular cholesterol flux in TMZ-induced cell death is still under investigation. Data are contradictory, some showing that statins reduced TMZ-induced cell death and therefore proposed the use of TMZ with soluble cholesterol which could potentially serve as combination therapy to treat glioblastoma (80), while other data proved that simvastatin promotes TMZinduced apoptosis in glioblastoma cells (52). Statins may potentially serve as a new therapeutic approach for combination therapy in glioblastoma (81). The effect of statins may be due to autophagy modulated by the mevalonate pathway $(82,83)$, through geranylgeranylation of the small GTPase molecule Rabll (82). Geranylgeranyl-pyrophosphate, which is produced by the mevalonate cascade, plays an important role in the prenylation of the superfamily of Ras-like GTPase proteins known as the Rab family (84). Rab GTPases are involved in vesicular trafficking, where Rabll and Rab7 are critical components for autophagosome formation and autophagosome-lysosome fusion (85). Thus, autophagy flux is inhibited due to the decreased prenylation of Rabll and Rab7, which is a result of the inhibition of mevalonate pathway by statins $(84,85)$. Therefore the inhibition of mevalonate pathway followed by autophagy inhibition leads to apoptotic cell death $(83,86)$. Long-term consumption of statins increased survival rate of various cancer patients (87). The same result was shown with glioblastoma patients (88). Cancers with overactive Myc, which is a transcription factor that regulates cholesterol synthesis, have been observed with amplified expression of HMGCR and sensitivity to statins $(89,90)$. Thus, inhibiting autophagy with statins or other molecules via the mevalonate pathway or other channels could also be a new approach to treat glioblastoma.

\section{Sterol regulatory element-binding protein (SREBP)}

Sterol regulatory element-binding protein (SREBP) may also be a novel therapeutic target. Intracellular levels of cholesterol and fatty acids are controlled through a feedback regulatory system mediated by SREBPs (91). SREBP-la can activate all target genes. SREBP-1c primarily regulates fatty acid metabolism, such as by regulating the fatty acid synthase (FASN) gene. SREBP-2 is mainly responsible for cholesterol-related genes, such as the HMG-CoA reductase (HMGCR) and lowdensity lipoprotein receptor (LDLR) gene (92). Cholesterol and fatty acid synthesis decreases following the inhibition of SREBPs expression. Therefore, SREBP and its pathways can be novel targets for the treatment of glioblastoma (93). The oncogenic signaling EGFR-PI3K-Akt pathway is involved in boosting lipid levels and their uptake into glioblastoma cells by the upregulation of the sterol regulatory element-binding protein (SREBP-1) (94). Thus, inhibition of EGFR-PI3K-Akt signaling by the EGFR inhibitor lapatinib suppresses SREBP-1 nuclear translocation sensitized glioblastoma xenografts in mice, resulting in cell death (95). Phytol and retinol, inhibitors of SREBP-1 synthesis, are able to induce glioblastoma cell death by interfering with fatty acid and cholesterol metabolism (94). Betulin specifically inhibits the maturation of SREBP by inducing the interaction of SREBP cleavage-activating protein (SCAP) and insulin-induced gene (Insig), which leads 
to the endoplasmic reticulum-retention of SCAP-SREBP complex. Betulin decreases the biosynthesis of cholesterol and fatty acids (92) and could lead to glioblastoma cell death. The flavanol quercetin decreased the expression of SREBP-1 and SREBP-2, decreasing the viability of glioblastoma cells (96). Oxysterols such as 22 (R)-hydroxycholesterol and 24 (S), 25-epoxycholesterol appear to inhibit cholesterol biosynthesis, possibly via their accumulation, which inhibits the cleavage of SREBP-2 (97).

\section{Cholesterol derivatives: oxysterols}

Cholesterol and its metabolites (precursors and derivatives) play an important role in cancer (98). Certain cholesterol metabolites such as estrogens and androgens can promote cancer, while others such as glucocorticoids suppress cancer (99). Oxysterols such as 7-ketocholesterol (7-KC) and 25-hydroxycholesterol (25-OHC) are products of cholesterol oxidation obtained mainly either by cholesterol autooxidation or enzymatic oxidation of cholesterol, respectively, and are potent suppressors of HMGCR activity (100, 101). Suppression of reductase prevents cells from synthesizing cholesterol which could inhibit cell growth (101). The chronological study of the cytotoxic activities of oxysterols has led to an interest in their activities on metabolism. Oxysterols and pro-drugs derived from oxysterols were initially studied for their cytotoxicity; mainly their ability to induce cell death. Then, due to their pro-inflammatory properties, their immunomodulatory-anticancerous properties were also examined. As some oxysterols can inhibit the activity of HMGCR, their ability to act on cholesterol metabolism was investigated. Oxysterols quickly emerged as interesting molecules in cancer due to their greatly altered levels in some tumors and due to their ability to promote cellular oxidative stress and cytotoxicity $(102,103)$. Currently, oxysterols and their involvement in cholesterol metabolism constitute a new field of research, and their implication in oncogenic pathways is also of interest, as some of them appear to have mutagenic properties (104).

Oxysterols can act on G protein-coupled receptors (GPCR) (e.g. Epstein-Barr virus-induced gene 2 [EBI2]), smoothened (SMO), chemokine (C-X-C motif) receptor 2 [CXCR2]), nuclear receptors (LXR, retinoic acid receptor-related orphan receptor (ROR), estrogen receptor $[E R \alpha]$ ), anti-estrogen binding site (AEBS) (105) and through transporters or regulatory proteins (106). The mechanisms by which oxysterols may influence proliferation are manifold: two types of effects related to AEBS are the inhibition of cholesterol epoxide hydrolase (ChEH) (107, 108) and the inhibition of cholesterol biosynthesis (109), leading to increases in levels of cholesterol intermediates (110). Resulting sterol accumulation is associated with the development of autophagic features (111-114), and can lead to survival or lethal autophagy depending on concentrations and time of treatment (115). B-ring oxysterols, such as 7-KC, 7-ketocholestanol, and 6-ketocholestanol (116) bind to AEBS. Certain oxysterols can suppress the activation of SREBPs by binding to an oxysterol sensing protein in the endoplasmic reticulum, Insig (101-105). Some oxysterols can accelerate the degradation of the key cholesterol biosynthetic enzyme, HMGCR, and/or serve as natural ligand activators of LXR (103, 105, 117-119). Oxysterols have been shown to induce apoptosis in a variety of cell lines: human monocyte blood cells (U937), murine lymphoma cells (RDM4), human vascular endothelial cells (HUVECs), human artery smooth 
muscle cells (A7R5), human colon cancer cells (Caco-2), chinese hamster ovary cells (CHO), mastocytoma cells (P815) and T cell derived human leukemia lines (CEM-Cl and CEM-C7) as well as on numerous types of nerve cells (158N, BV-2 and N2a) (104, 120-128). There are two major apoptotic pathways; the death receptor or extrinsic pathway $(129,130)$ and the mitochondrial or intrinsic pathway $(131,132)$. 27-hydroxycholesterol (27-OHC) has recently been shown to act as an estrogen receptor agonist in breast cancer, contributing to tumor growth and metastasis (133). To date, several works have concentrated on oxysterols oxidized at C7, in particular, 7-KC and 7 $\beta$-hydroxycholesterol ( $7 \beta$-OHC). $7 \beta$-OHC derivatives, some blocked at C-3-OH group and others phosphodiesters of $7 \beta-O H C$, were synthesized and showed similar toxicity to their parent compound under in vitro conditions $(127,134) .7-\mathrm{KC}$ and $7 \beta-\mathrm{OHC}$ are potent inducers of cell death and trigger apoptosis through the mitochondrial pathway on several cell types (135-139). 7 -KC and $7 \beta-O H C$ induce a mode of cell death defined as oxiapoptophagy (OXIdative stress + APOPTOsis + autoPHAGY) (140). Consequently, cholesterol derivatives and notably oxysterols, constitute an interesting class of molecules which are of huge interest in oncology, and may form a new class of antitumor agents.

\section{Natural and synthetic cholesterol derivatives}

We have exploited the anti-proliferative and immunosuppressive properties of cholesterol derivatives to study their effect on C6 cells which are the most common experimental models used in neuro-oncology to study glioblastoma (141-145). We have compared the cytotoxic effects of the following natural and synthetic cholesterol derivatives: natural compounds (7ß-OHC, 22 (R)-hydroxycholesterol (22R-OHC), 24 (S)-hydroxycholesterol (24 (S)-OHC)). Synthetic compounds (22(R)-hydroxy- $\Delta^{9}$-cholestanol (22R-ISO-OHC), 23-(4-Methylfuran-2,5-dione)-3 $\alpha$-hydroxy-24-nor-5 $\beta$-cholane (LITHO la), 23-(4-Methylfuran-2,5-dione)-3 $\alpha, 7 \alpha$-dihydroxy-24-nor-5(3-cholane) (CHENO 1b), 23-(4-Methyl-1H-pyrrole-2,5-dione)-3 $\alpha$-hydroxy-24-nor-5 $\beta$-cholane (LITOMAL 7a), 23-(4-Methyl-1H-pyrrole-2,5-dione)-3 $\alpha, 7 \alpha, 12 \alpha$-trihydroxy-24nor-5 $\beta$-cholane (COLMAL 7f) and ethanol maleimide derivatives of litocholic and chenodeoxycholic acid (LITOMET, CHENOMET)) $(146,147)$. The sytematic name of LITOMET is (23-((2-hydroxyethyl)-4-methyl-1H-pyrrole-2,5-dione)-3 $\alpha$ hydroxy-24-nor-5 $\beta$-cholane) and the systematic name of CHENOMET is (23-((2-hydroxyethyl)-4-methyl-1H-pyrrole-2,5-dione)- 3 $\alpha, 7 \alpha$-dihydroxy-24nor-5 $\beta$-cholane). We evaluated the effects on cell morphology by phase contrast microscopy, on cell viability by the MTT test, on esterase activity by the FDA test, on cell survival by the clonogenicity test, on mitochondria by measuring the mitochondrial transmembrane potential $(\Delta \Psi \mathrm{m})$ by staining with 3,3'-dihexyloxacarbocyanine iodide $\left(\mathrm{DiOC}_{6}(3)\right)$, on the plasma membrane also indicating cell mortality by propidium iodide (PI) staining, on lysosomes by acridine orange (AO) staining, on the cell cycle by detection of cells in phase (G2+M) after PI staining, on autophagy by quantification of LC3-II and LC3-I protein expression by Western blot (LC-3II/LC-3I ratio). PI, $\mathrm{DiOC}_{6}(3)$ and $\mathrm{AO}$ staining were measured by flow cytometry. Based on these tests a multidimensional and multivariate heatmap was made (Figure 3). The heatmap obtained allows for a comparative study of the cytotoxicity of the cholesterol derivatives studied, some of which trigger a non-apoptotic mode of cell death with characteristics of autophagy leading an increase of the ratio LC3-IILC3-I. Our results underline that cholesterol derivatives, including oxysterols, are cytotoxic on tumor cells and can potentially constitute a new group of molecules to treat glioblastoma. 
A

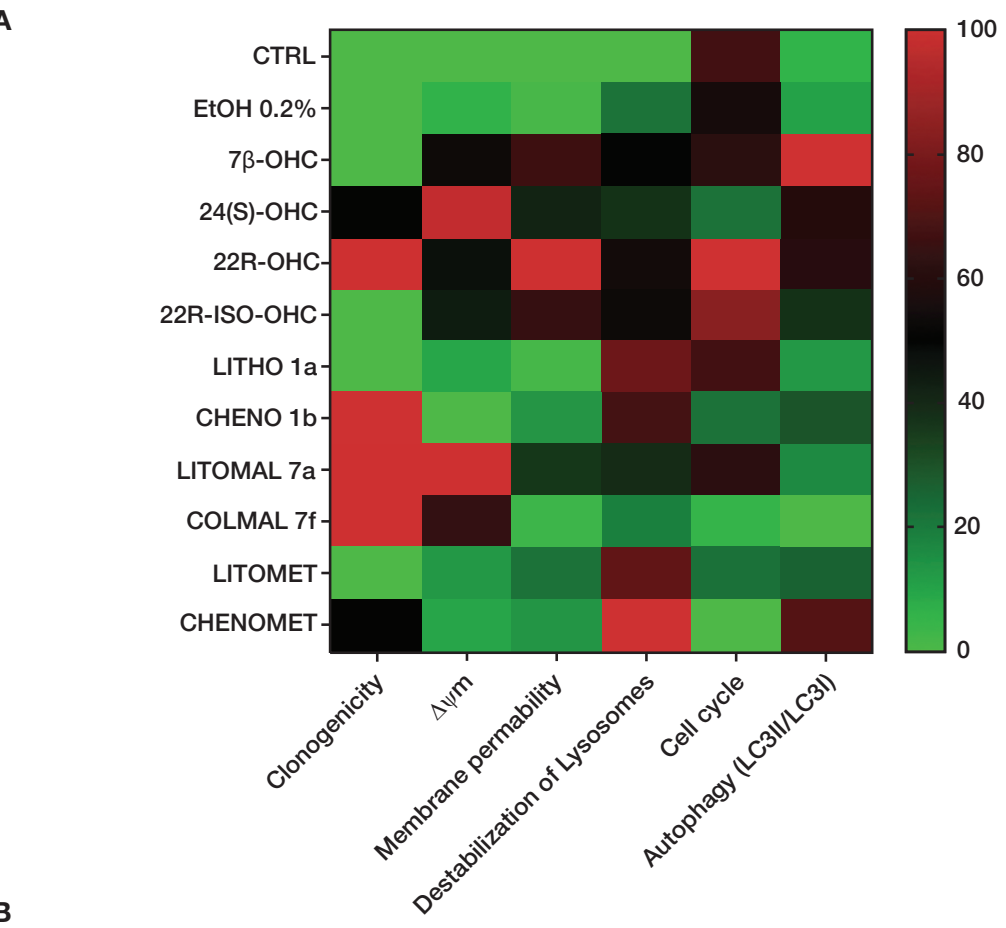

B

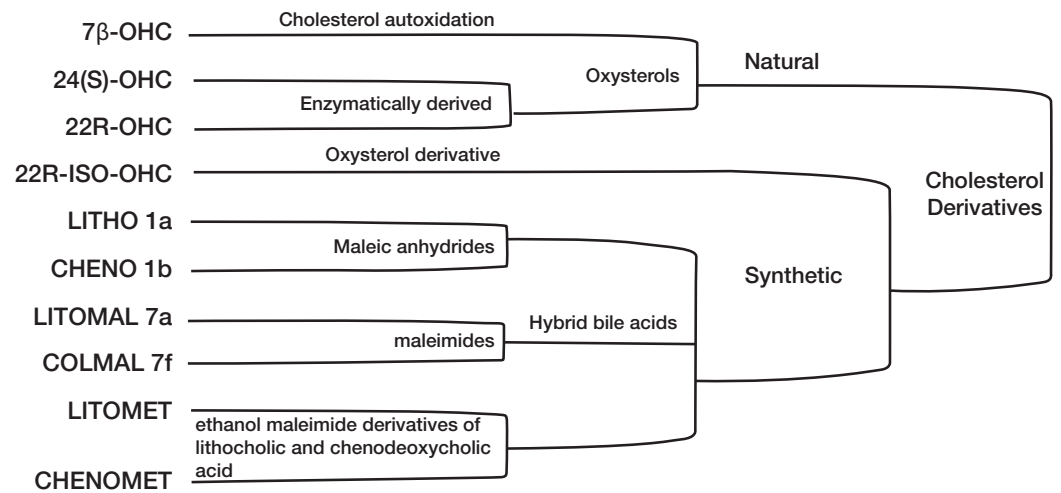

Figure 3. Heatmap and Cholesterol derivatives classification. A. The heatmap is a color-grading system comparing the effects of cholesterol derivatives on rat C6 glioblastoma cells. It grades from green (little or no effect) to red (maximum effect) based on clonogenicity, mitochondrial membrane potential $(\Delta \Psi \mathrm{m})$, permeability of the plasma membrane, destabilization of lysosomes, effects on the cell cycle and activity on autophagy measured by the LC3II/LC3I ratio. B. Classification comparing natural and synthetic cholesterol derivatives.

\section{Mitochondria as therapeutic targets}

Mitochondria and their increased cholesterol levels have been implicated in many pathological processes, including cancer $(148,149)$. Mitochondria are the organelles responsible for primary cellular ATP and ROS production, ensuring the 
survival of cells by providing them with energy in the form of ATP and, under certain circumstances, to their destruction through their active participation in apoptosis. Mitochondria were shown to be crucial for the regulation of various physiological processes (150). Mitochondrial (mt) dysfunction is frequently observed in glioblastoma and has been linked to mt energy metabolism alterations, $\mathrm{mt}$ structure abnormalities, disturbances in mt membrane potential regulation, genomic mutations in mtDNA and apoptotic signaling, as well as to mutations involving the Krebs cycle enzyme isocitrate dehydrogenase (IDH) $(148,151)$. Mitochondria-targeted therapeutic strategies in glioblastoma include metabolic modulation with emphasis on dichloroacetate, a pyruvate dehydrogenase kinase (PDK) inhibitor $(150,152,153)$ and mitochondrial-mediated apoptosis induced by tricyclic antidepressants (154), as well as mitochondrial aberrant signaling cascades with natural compounds such as phytosterol $(148,155)$. Mitochondria is also involved in the synthesis of cholesterol and 27-OHC, making it an interesting target for metabolic therapy.

\section{Use of antisense therapies directed against the IGF-IR}

The modification of the expression of growth factors or their receptors is implicated in tumor progression (156). The insulin-like growth factor type I receptor (IGF-IR) has been shown to contribute to the tumorigenesis process (157). IGF-I may also contribute to abnormalities of cholesterol metabolism $(158,159)$. IGF-I binding triggers the activation of several intracellular signaling cascades involving the mitogen-activated protein kinase (MAP-K) and the PI3K pathways (157). Inhibition of the expression or function of this receptor within tumor cells has been successfully achieved by different approaches, including the use of ribonucleic acid (RNA) or oligonucleotides antisense. Antisense RNAs and oligonucleotides inhibit the translation of messenger RNA (mRNA) $(160,161)$. These antisense approaches to control IGF-IR expression are indeed capable, in experimental models, of blocking the expression of the receptor in glioblastoma cells and inhibiting their tumorigenesis in vivo by inducing cellular apoptosis and/or an immune response $(162,163)$.

\section{Targeted nanotherapy}

Glioblastoma therapies are not fully effective due to the existence of a series of barriers that prevent them from reaching these tumors. Great hopes are placed in nanotherapy, since nano-drugs could improve the delivery of glioblastoma drugs (164). Nanotherapy could be used to address drugs specifically acting on cholesterol metabolism in glioblastoma cells. Moreover, if nanoparticles are magnetic or superparamagnetic, they may be guided in a magnetic field. Nanotherapy could increase the therapeutic effectiveness of chemotherapeutic agents while reducing their side effects and favoring their passage through the BBB (165). However, two drawbacks of nanotherapy should be stated: (i) the need to remove certain metals from the treatment area when using metal nanoparticles, such as iron oxide or gold nanoparticles, and (ii) the indefinite exclusion of magnetic resonance imaging (MRI) for subsequent diagnosis of tumor progression (166). Nanoparticles can accumulate specifically in cancer cells through two targeting mechanisms: either they target passive cancer tissues by extravasation of nanoparticles through the 
increased permeability of endothelial cell junctions in the tumor, or they target the tumor cell by functionalizing the surface of the nanoparticles with ligands which specifically bind to receptors that are overexpressed at the cancer cell surface (167). Another possible treatment for glioblastoma patients could be intra-tumoral thermotherapy using magnetic iron-oxide nanoparticles combined with radiotherapy (168). Even a 7-KC-containing nano-emulsion could be of interest to treat glioblastoma since $7-\mathrm{KC}$ has been successfully used to reduce melanoma growth (169).

\section{CONCLUSION}

Cholesterol derivatives, including oxysterols, that have anti-proliferative and immunosuppressive properties, could have a great potential for the treatment of cancer $(170,171)$. Furthermore, oxysterols modulate the activity of several proteins and consequently affect many cellular functions and influence various physiological processes including cholesterol metabolism by maintaining cellular cholesterol level (105). Moreover, oxysterols have been revealed to modulate the function of immune cells and cancer growth. These effects can be dependent on the activation of the oxysterol-binding LXRs (170). At micromolar concentrations, some oxysterols are cytotoxic towards cancer cells in culture, and reduce the growth of murine transplanted tumors (172). Thus, due to the important role of oxysterols in cancer, possible applications of cholesterol derivatives as immunosuppressants or as active anticancer agents in metabolic therapy are promising. $\mathrm{Tt}$ has been shown that several cholesterol derivatives, which may or may not be LXR-agonists, induce numerous organelle dysfunctions including mitochondria, lysosome, peroxisome and endoplasmic reticulum, and are also autophagic inducers, these molecules could thus be of interest in the treatment of glioblastoma by targeting their cancer cells' metabolism.

Acknowledgement: This work was supported by grants from Univ. Tunis El Manar (Tunis, Tunisia) and Univ. Bourgogne (Dijon, France).

Conflict of interest: The authors declare no potential conflict of interest with respect to research, authorship and/or publication of this chapter.

Copyright and permission statement: The authors confirm that the materials included in this chapter do not violate copyright laws. Where relevant, appropriate permissions have been obtained from the original copyright holder(s), and all original sources have been appropriately acknowledged or referenced.

\section{REFERENCES}

1. Patel AP, Fisher JL, Nichols E, Abd-Allah F, Abdela J, Abdelalim A, et al. Global, regional, and national burden of brain and other CNS cancer, 1990-2016: a systematic analysis for the Global Burden of Disease Study 2016. Lancet Neurol. 2019;18(4):376-393 
2. Leece R, Xu J, Ostrom QT, Chen Y, Kruchko C, Barnholtz-Sloan JS. Global incidence of malignant brain and other central nervous system tumors by histology, 2003-2007. Neuro-Oncology. 2017;19(11):1553-64. https://doi.org/10.1093/neuonc/nox091

3. Masui K, Mischel PS, Reifenberger G. Molecular classification of gliomas. Handb Clin Neurol. 2016;134:97-120. https://doi.org/10.1016/B978-0-12-802997-8.00006-2

4. Louis DN, Perry A, Reifenberger G, von Deimling A, Figarella-Branger D, Cavenee WK, et al. The 2016 World Health Organization Classification of Tumors of the Central Nervous System: a summary. Acta Neuropathol. 2016;131(6):803-20. https://doi.org/10.1007/s00401-016-1545-1

5. Figarella-Branger D, Colin C, Coulibaly B, Quilichini B, Maues De Paula A, Fernandez C, et al. Classification histologique et moléculaire des gliomes. Revue Neurologique. 2008;164(6-7):505-15. https://doi.org/10.1016/j.neurol.2008.03.011

6. Libby CJ, Tran AN, Scott SE, Griguer C, Hjelmeland AB. The pro-tumorigenic effects of metabolic alterations in glioblastoma including brain tumor initiating cells. Biochim Biophys Acta Rev Cancer. 2018;1869(2):175-88. https://doi.org/10.1016/j.bbcan.2018.01.004

7. Park JH, Pyun WY, Park HW. Cancer Metabolism: Phenotype, Signaling and Therapeutic Targets. Cells. 2020;9(10):2308. https://doi.org/10.3390/cells9102308

8. Hanahan D, Weinberg RA. Hallmarks of cancer: the next generation. Cell. 2011;144(5):646-74. https://doi.org/10.1016/j.cell.2011.02.013

9. Eberhard A, Kahlert S, Goede V, Hemmerlein B, Plate KH, Augustin HG. Heterogeneity of angiogenesis and blood vessel maturation in human tumors: implications for antiangiogenic tumor therapies. Cancer Res. 2000;60(5):1388-93.

10. Warburg O, Wind F, Negelein E. The metabolism of tumors in the body. J Gen Physiol. 1927;8(6): 519-30. https://doi.org/10.1085/jgp.8.6.519

11. Moreno-Sánchez R, Rodríguez-Enríquez S, Marín-Hernández A, Saavedra E. Energy metabolism in tumor cells: Glycolytic and mitochondrial metabolism of tumor cells. FEBS J. 2007;274(6): 1393-418. https://doi.org/10.1111/j.1742-4658.2007.05686.x

12. Weinberg SE, Chandel NS. Targeting mitochondria metabolism for cancer therapy. Nat Chem Biol. 2015;11(1):9. https://doi.org/10.1038/nchembio.1712

13. Weinberg F, Hamanaka R, Wheaton WW, Weinberg S, Joseph J, Lopez M, et al. Mitochondrial metabolism and ROS generation are essential for Kras-mediated tumorigenicity. Proc Natl Acad Sci. 2010;107(19):8788-93. https://doi.org/10.1073/pnas.1003428107

14. Park JK, Coffey NJ, Limoges A, Le A. The Heterogeneity of Lipid Metabolism in Cancer. In: Le A. (eds) The Heterogeneity of Cancer Metabolism. Advances in Experimental Medicine and Biology, vol 1063. Springer, Cham.2018:1063: 33-55. https://doi.org/10.1007/978-3-319-77736-8_3

15. Bensaad K, Favaro E, Lewis CA, Peck B, Lord S, Collins JM, et al. Fatty acid uptake and lipid storage induced by HIF-1 $\alpha$ contribute to cell growth and survival after hypoxia-reoxygenation. Cell Rep. 2014;9(1):349-65. https://doi.org/10.1016/j.celrep.2014.08.056

16. Kamphorst JJ, Cross JR, Fan J, de Stanchina E, Mathew R, White EP, et al. Hypoxic and Rastransformed cells support growth by scavenging unsaturated fatty acids from lysophospholipids. Proc Natl Acad Sci. 2013;110(22):8882-7. https://doi.org/10.1073/pnas.1307237110

17. Cheung EC, DeNicola GM, Nixon C, Blyth K, Labuschagne CF, Tuveson DA, et al. Dynamic ROS Control by TIGAR Regulates the Initiation and Progression of Pancreatic Cancer. Cancer Cell. 2020;37(2):168-182.e4. https://doi.org/10.1016/j.ccell.2019.12.012

18. Zaal EA, Berkers CR. The Influence of Metabolism on Drug Response in Cancer. Front Oncol. 2018; 8:500. https://doi.org/10.3389/fonc.2018.00500

19. Ostrom QT, Gittleman H, Farah P, Ondracek A, Chen Y, Wolinsky Y, et al. CBTRUS Statistical Report: Primary Brain and Central Nervous System Tumors Diagnosed in the United States in 2006-2010. Neuro-Oncology. 2013;15(suppl 2):iil-56. https://doi.org/10.1093/neuonc/not151

20. Song W, Ruder AM, Hu L, Li Y, Ni R, Shao W, et al. Genetic epidemiology of glioblastoma multiforme: confirmatory and new findings from analyses of human leukocyte antigen alleles and motifs. PLoS One. 2009;4(9):e7157. https://doi.org/10.1371/journal.pone.0007157

21. McNeill KA. Epidemiology of brain tumors. Neurol Clin. 2016;34(4):981-98. https://doi.org/ 10.1016/j.ncl.2016.06.014 
22. Butowski NA. Epidemiology and Diagnosis of Brain Tumors: Continuum: Lifelong Learning in NeuroOncology. 2015;21:301-13. https://doi.org/10.1212/01.CON.0000464171.50638.fa

23. Farrell CJ, Plotkin SR. Genetic Causes of Brain Tumors: Neurofibromatosis, Tuberous Sclerosis, von Hippel-Lindau, and Other Syndromes. Neurol Clin. 2007;25(4):925-46. https://doi.org/10.1016/j. ncl.2007.07.008

24. Rice T, Lachance DH, Molinaro AM, Eckel-Passow JE, Walsh KM, Barnholtz-Sloan J, et al. Understanding inherited genetic risk of adult glioma - a review. Neurooncol Pract. 2016;3(1):10-6. https://doi.org/10.1093/nop/npv026

25. Vilchez RA, Kozinetz CA, Arrington AS, Madden CR, Butel JS. Simian virus 40 in human cancers. Am J Med. 2003;114(8):675-84. https://doi.org/10.1016/S0002-9343(03)00087-1

26. Crawford JR, Santi MR, Thorarinsdottir HK, Cornelison R, Rushing EJ, Zhang H, et al. Detection of human herpesvirus-6 variants in pediatric brain tumors: Association of viral antigen in low grade gliomas. J Clin Virol. 2009;46(1):37-42. https://doi.org/10.1016/j.jcv.2009.05.011

27. Chi J, Gu B, Zhang C, Peng G, Zhou F, Chen Y, et al. Human Herpesvirus 6 Latent Infection in Patients With Glioma. J Infect Dis. 2012;206(9):1394-8. https://doi.org/10.1093/infdis/jis513

28. McFaline-Figueroa JR, Wen PY. The Viral Connection to Glioblastoma. Curr Infect Dis Rep. 2017;19(2):5. https://doi.org/10.1007/s11908-017-0563-z

29. Alifieris C, Trafalis DT. Glioblastoma multiforme: Pathogenesis and treatment. Pharmacol Ther. 2015;152:63-82. https://doi.org/10.1016/j.pharmthera.2015.05.005

30. Thakkar JP, Dolecek TA, Horbinski C, Ostrom QT, Lightner DD, Barnholtz-Sloan JS, et al. Epidemiologic and molecular prognostic review of glioblastoma. Cancer Epidemiol Biomarkers Prev.2014;23(10):1985-96. https://doi.org/10.1158/1055-9965.EPI-14-0275

31. Young RM, Jamshidi A, Davis G, Sherman JH. Current trends in the surgical management and treatment of adult glioblastoma. Ann Transl Med. 2015;3(9):15.

32. Bleeker FE, Lamba S, Zanon C, Molenaar RJ, Hulsebos TJ, Troost D, et al. Mutational profiling of kinases in glioblastoma. BMC Cancer. 2014;14(1):718. https://doi.org/10.1186/1471-2407-14-718

33. Bleeker FE, Molenaar RJ, Leenstra S. Recent advances in the molecular understanding of glioblastoma. J Neurooncol. 2012;108(1):11-27. https://doi.org/10.1007/s11060-011-0793-0

34. Appin CL, Gao J, Chisolm C, Torian M, Alexis D, Vincentelli C, et al. Glioblastoma with Oligodendroglioma Component (GBM-O): Molecular Genetic and Clinical Characteristics: Molecular and Clinical Characteristics of GBM-O. Brain Pathol. 2013;23(4):454-61. https://doi.org/10.1111/ bpa. 12018

35. Kleihues P, Ohgaki H. Primary and secondary glioblastomas: from concept to clinical diagnosis. Neuro-oncology. 1999;1(1):44-51. https://doi.org/10.1093/neuonc/1.1.44

36. Ohgaki H, Kleihues P. The Definition of Primary and Secondary Glioblastoma. Clin Cancer Res. 2013;19(4):764-72. https://doi.org/10.1158/1078-0432.CCR-12-3002

37. Furnari FB, Fenton T, Bachoo RM, Mukasa A, Stommel JM, Stegh A, et al. Malignant astrocytic glioma: genetics, biology, and paths to treatment. Genes Dev. 2007;21(21):2683-710. https://doi. org/10.1101/gad.1596707

38. Dimberg A. The glioblastoma vasculature as a target for cancer therapy. Biochem Soc Trans. 2014;42(6):1647-52. https://doi.org/10.1042/BST20140278

39. Jain RK. Normalizing Tumor Microenvironment to Treat Cancer: Bench to Bedside to Biomarkers. JCO. 2013;31(17):2205-18. https://doi.org/10.1200/JCO.2012.46.3653

40. Molenaar RJ. Ion Channels in Glioblastoma. ISRN Neurol. 2011;2011:1-7. https://doi. org/10.5402/2011/590249

41. Linninger A, Hartung GA, Liu BP, Mirkov S, Tangen K, Lukas RV, et al. Modeling the diffusion of D-2-hydroxyglutarate from IDHl mutant gliomas in the central nervous system. Neuro-Oncology. 2018;20(9):1197-206. https://doi.org/10.1093/neuonc/noy051

42. van Lith SAM, Molenaar R, van Noorden CJF, Leenders WPJ. Tumor cells in search for glutamate: an alternative explanation for increased invasiveness of IDHl mutant gliomas. Neuro-Oncology. 2014;16(12):1669-70. https://doi.org/10.1093/neuonc/noul52

43. Murat A, Migliavacca E, Gorlia T, Lambiv WL, Shay T, Hamou M-F, et al. Stem Cell-Related "SelfRenewal" Signature and High Epidermal Growth Factor Receptor Expression Associated With 
Resistance to Concomitant Chemoradiotherapy in Glioblastoma. JCO. 2008;26(18):3015-24. https:// doi.org/10.1200/JCO.2007.15.7164

44. Zalba S, ten Hagen TLM. Cell membrane modulation as adjuvant in cancer therapy. Cancer Treat Rev. 2017;52:48-57. https://doi.org/10.1016/j.ctrv.2016.10.008

45. Rysman E, Brusselmans K, Scheys K, Timmermans L, Derua R, Munck S, et al. De novo Lipogenesis Protects Cancer Cells from Free Radicals and Chemotherapeutics by Promoting Membrane Lipid Saturation. Cancer Res. 2010;70(20):8117-26. https://doi.org/10.1158/0008-5472.CAN-09-3871

46. Jeon S-M, Chandel NS, Hay N. AMPK regulates NADPH homeostasis to promote tumour cell survival during energy stress. Nature. 2012;485(7400):661-5. https://doi.org/10.1038/nature11066

47. Ayala A, Muñoz MF, Argüelles S. Lipid Peroxidation: Production, Metabolism, and Signaling Mechanisms of Malondialdehyde and 4-Hydroxy-2-Nonenal. Oxid Med Cell Longev. 2014;2014: 1-31. https://doi.org/10.1155/2014/360438

48. Wang D, DuBois RN. Eicosanoids and cancer. Nat Rev Cancer. 2010;10(3):181-93. https://doi. org/10.1038/nrc2809

49. Keckesova Z, Donaher JL, De Cock J, Freinkman E, Lingrell S, Bachovchin DA, et al. LACTB is a tumour suppressor that modulates lipid metabolism and cell state. Nature. 2017;543(7647):681-6. https://doi.org/10.1038/nature21408

50. Pascual G, Avgustinova A, Mejetta S, Martín M, Castellanos A, Attolini CS-O, et al. Targeting metastasisinitiating cells through the fatty acid receptor CD36. Nature. 2017;541(7635):41-5. https://doi. org/10.1038/nature20791

51. Tadros S, Shukla SK, King RJ, Gunda V, Vernucci E, Abrego J, et al. De Novo Lipid Synthesis Facilitates Gemcitabine Resistance through Endoplasmic Reticulum Stress in Pancreatic Cancer. Cancer Res. 2017;77(20):5503-17. https://doi.org/10.1158/0008-5472.CAN-16-3062

52. Pirmoradi L, Seyfizadeh N, Ghavami S, Zeki AA, Shojaei S. Targeting cholesterol metabolism in glioblastoma: a new therapeutic approach in cancer therapy. J Investig Med. 2019;67(4):715-9. https:// doi.org/10.1136/jim-2018-000962

53. Björkhem I, Meaney S. Brain cholesterol: long secret life behind a barrier. Arterioscler Thromb Vasc Biol. 2004;24(5):806-15. https://doi.org/10.1161/01.ATV.0000120374.59826.1b

54. Villa GR, Hulce JJ, Zanca C, Bi J, Ikegami S, Cahill GL, et al. An LXR-Cholesterol Axis Creates a Metabolic Co-Dependency for Brain Cancers. Cancer Cell. 2016;30(5):683-93. https://doi. org/10.1016/j.ccell.2016.09.008

55. Gliozzi M, Musolino V, Bosco F, Scicchitano M, Scarano F, Nucera S, et al. Cholesterol homeostasis: Researching a dialogue between the brain and peripheral tissues. Pharmacol Res. 2020;105215. https://doi.org/10.1016/j.phrs.2020.105215

56. Hayashi H, Campenot RB, Vance DE, Vance JE. Glial Lipoproteins Stimulate Axon Growth of Central Nervous System Neurons in Compartmented Cultures. J Biol Chem. 2004;279(14):14009-15. https://doi.org/10.1074/jbc.M313828200

57. York AG, Bensinger SJ. Subverting sterols: rerouting an oxysterol-signaling pathway to promote tumor growth. J Exp Med. 2013;210(9):1653-6. https://doi.org/10.1084/jem.20131335

58. Dufour J, Viennois E, De Boussac H, Baron S, Lobaccaro J-M. Oxysterol receptors, AKT and prostate cancer. Curr Opin Pharmacol. 2012;12(6):724-8. https://doi.org/10.1016/j.coph.2012.06.012

59. Zelcer N, Hong C, Boyadjian R, Tontonoz P. LXR Regulates Cholesterol Uptake Through IdolDependent Ubiquitination of the LDL Receptor. Science. 2009;325(5936):100-4. https://doi. org/10.1126/science.1168974

60. Lindholm D, Bornhauser BC, Korhonen L. Mylip makes an Idol turn into regulation of LDL receptor. Cell Mol Life Sci. 2009;66(21):3399-402. https://doi.org/10.1007/s00018-009-0127-y

61. Sawamura T. New Idol for Cholesterol Reduction? Clin Chem. 2009;55(12):2082-4. https://doi. org/10.1373/clinchem.2009.134023

62. Feigin VL, Abajobir AA, Abate KH, Abd-Allah F, Abdulle AM, Abera SF, et al. Global, regional, and national burden of neurological disorders during 1990-2015: a systematic analysis for the Global Burden of Disease Study 2015. Lancet Neurol. 2017;16(11):877-97. 
63. Patel D, Ahmad F, Kambach DM, Sun Q, Halim AS, Kramp T, et al. LXR $\beta$ controls glioblastoma cell growth, lipid balance, and immune modulation independently of ABCAl. Sci Rep. 2019;9(1):15458. https://doi.org/10.1038/s41598-019-51865-8

64. Preusser M, Marosi C. Advances in brain tumour classification and therapy. Nat Rev Neurol. 2017;13(2):71-2. https://doi.org/10.1038/nrneurol.2017.3

65. Park KB, Johnson WD, Dempsey RJ. Global Neurosurgery: The Unmet Need. World Neurosurg. 2016;88:32-5. https://doi.org/10.1016/j.wneu.2015.12.048

66. Lawson HC, Sampath P, Bohan E, Park MC, Hussain N, Olivi A, et al. Interstitial chemotherapy for malignant gliomas: the Johns Hopkins experience. J Neurooncol. 2007;83(1):61-70. https://doi. org/10.1007/s11060-006-9303-1

67. Ostrom QT, Cioffi G, Gittleman H, Patil N, Waite K, Kruchko C, et al. CBTRUS Statistical Report: Primary Brain and Other Central Nervous System Tumors Diagnosed in the United States in 20122016. Neuro-Oncology. 2019;21(Supplement_5):vl-100. https://doi.org/10.1093/neuonc/noz150

68. Gallego O. Nonsurgical treatment of recurrent glioblastoma. Curr Oncol. 2015;22(4):273. https://doi. org/10.3747/co.22.2436

69. Sheehan JP, Shaffrey ME, Gupta B, Larner J, Rich JN, Park DM. Improving the radiosensitivity of radioresistant and hypoxic glioblastoma. Future Oncol. 2010;6(10):1591-601. https://doi.org/10.2217/ fon. 10.123

70. Hanna C, Lawrie TA, Rogozińska E, Kernohan A, Jefferies S, Bulbeck H, et al. Treatment of newly diagnosed glioblastoma in the elderly: a network meta-analysis. Cochrane Database Syst Rev. 2020(3). https://doi.org/10.1002/14651858.CD013261.pub2

71. Chamberlain MC, Glantz MJ, Chalmers L, Van Horn A, Sloan AE. Early necrosis following concurrent Temodar and radiotherapy in patients with glioblastoma. J Neurooncol. 2007;82(1):81-3. https://doi. org/10.1007/s11060-006-9241-y

72. Wilcox JA, Ramakrishna R, Magge R. Immunotherapy in Glioblastoma. World Neurosurg. 2018;116:518-28. https://doi.org/10.1016/j.wneu.2018.04.020

73. Wang G, Fu XL, Wang JJ, Guan R, Tang XJ. Novel strategies to discover effective drug targets in metabolic and immune therapy for glioblastoma. Curr Cancer Drug Targets. 2017;17(1):17-39. https:// doi.org/10.2174/1568009616666160512145436

74. Luengo A, Gui DY, Vander Heiden MG. Targeting Metabolism for Cancer Therapy. Cell Chem Biol. 2017;24(9):1161-80. https://doi.org/10.1016/j.chembiol.2017.08.028

75. Guo D, Reinitz F, Youssef M, Hong C, Nathanson D, Akhavan D, et al. An LXR Agonist Promotes Glioblastoma Cell Death through Inhibition of an EGFR/AKT/SREBP-1/LDLR-Dependent Pathway. Cancer Discov. 2011;1(5):442-56. https://doi.org/10.1158/2159-8290.CD-11-0102

76. Hamm R, Zeino M, Frewert S, Efferth T. Up-regulation of cholesterol associated genes as novel resistance mechanism in glioblastoma cells in response to archazolid B. Toxicol Appl Pharmacol. 2014;281(1):78-86. https://doi.org/10.1016/j.taap.2014.08.033

77. Castello A, Hentze MW, Preiss T. Metabolic Enzymes Enjoying New Partnerships as RNA-Binding Proteins. Trends Endocrinol Metab. 2015;26(12):746-57. https://doi.org/10.1016/j.tem.2015.09.012

78. Zhu H, Han C, Wu T. MiR-17-92 cluster promotes hepatocarcinogenesis. Carcinogenesis. 2015;36(10):1213-22. https://doi.org/10.1093/carcin/bgv112

79. Cao S, Zheng J, Liu X, Liu Y, Ruan X, Ma J, et al. FXRl promotes the malignant biological behavior of glioma cells via stabilizing MIR17HG. J Exp Clin Cancer Res. 2019;38(1):1-22. https://doi. org/10.1186/s13046-018-0991-0

80. Yamamoto Y, Tomiyama A, Sasaki N, Yamaguchi H, Shirakihara T, Nakashima K, et al. Intracellular cholesterol level regulates sensitivity of glioblastoma cells against temozolomide-induced cell death by modulation of caspase- 8 activation via death receptor 5-accumulation and activation in the plasma membrane lipid raft. Biochem Biophys Res Commun. 2018;495(1):1292-9. https://doi.org/10.1016/j. bbrc.2017.11.113

81. Altwairgi AK, Alghareeb WA, AlNajjar FH, Alhussain H, Alsaeed E, Balbaid AA, et al. Atorvastatin in combination with radiotherapy and temozolomide for glioblastoma: a prospective phase II study. Invest New Drugs. 2020:1-6. https://doi.org/10.1007/s10637-020-00992-5 
82. Miettinen TP, Björklund M. Mevalonate pathway regulates cell size homeostasis and proteostasis through autophagy. Cell Rep. 2015;13(11):2610-20. https://doi.org/10.1016/j.celrep.2015.11.045

83. Tricarico PM, Romeo A, Gratton R, Crovella S, Celsi F. Lack of Prenylated Proteins, Autophagy Impairment and Apoptosis in SH-SY5Y Neuronal Cell Model of Mevalonate Kinase Deficiency. Cell Physiol Biochem. 2017;41(4):1649-60. https://doi.org/10.1159/000471235

84. Amaya C, Fader CM, Colombo MI. Autophagy and proteins involved in vesicular trafficking. FEBS Lett. 2015;589(22):3343-53. https://doi.org/10.1016/j.febslet.2015.09.021

85. Longatti A, Lamb CA, Razi M, Yoshimura SI, Barr FA, Tooze SA. TBC1D14 regulates autophagosome formation via Rab1l-and ULK1-positive recycling endosomesRecycling endosomes contribute to autophagosomes. J Cell Biol. 2012;197(5):659-75. https://doi.org/10.1083/jcb.201111079

86. Ghavami S, Yeganeh B, Stelmack GL, Kashani HH, Sharma P, Cunnington R, et al. Apoptosis, autophagy and ER stress in mevalonate cascade inhibition-induced cell death of human atrial fibroblasts. Cell Death Dis. 2012;3(6):e330-e330. https://doi.org/10.1038/cddis.2012.61

87. Nielsen SF, Nordestgaard BG, Bojesen SE. Statin Use and Reduced Cancer-Related Mortality. N Engl J Med. 2012;367(19):1792-802. https://doi.org/10.1056/NEJMoal201735

88. Gaist D, Hallas J, Friis S, Hansen S, Sørensen HT. Statin use and survival following glioblastoma multiforme. Cancer Epidemiol. 2014;38(6):722-7. https://doi.org/10.1016/j.canep.2014.09.010

89. Zhong C, Fan L, Yao F, Shi J, Fang W, Zhao H. HMGCR is necessary for the tumorigenecity of esophageal squamous cell carcinoma and is regulated by Myc. Tumor Biol. 2014;35(5):4123-9. https://doi. org/10.1007/s13277-013-1539-8

90. Wang X, Huang Z, Wu Q, Prager BC, Mack SC, Yang K, et al. MYC-Regulated Mevalonate Metabolism Maintains Brain Tumor-Initiating Cells. Cancer Res. 2017;77(18):4947-60. https://doi. org/10.1158/0008-5472.CAN-17-0114

91. Ye J, DeBose-Boyd RA. Regulation of Cholesterol and Fatty Acid Synthesis. Cold Spring Harb Perspect Biol. 2011;3(7):a004754-a004754. https://doi.org/10.1101/cshperspect.a004754

92. Xiao X, Song B-L. SREBP: a novel therapeutic target. Acta Biochimica et Biophysica Sinica. 2013;45(1):2-10. https://doi.org/10.1093/abbs/gms112

93. An Y, Zhang D-D, Yu H-L, Ma W-W, Lu Y-H, Liu Q-R, et al. 27-Hydroxycholesterol regulates cholesterol synthesis and transport in C6 glioma cells. Neurotoxicol. 2017;59:88-97. https://doi. org/10.1016/j.neuro.2017.02.001

94. Facchini G, Ignarro RS, Rodrigues-Silva E, Vieira AS, Lopes-Cendes I, Castilho RF, et al. Toxic effects of phytol and retinol on human glioblastoma cells are associated with modulation of cholesterol and fatty acid biosynthetic pathways. J Neurooncol. 2018;136(3):435-43. https://doi.org/10.1007/ s11060-017-2672-9

95. Guo D, Prins RM, Dang J, Kuga D, Iwanami A, Soto H, et al. EGFR Signaling Through an Akt-SREBP1-Dependent, Rapamycin-Resistant Pathway Sensitizes Glioblastomas to Antilipogenic Therapy. Sci Signal. 2009;2(101):ra82-ra82. https://doi.org/10.1126/scisignal.2000446

96. Damiano F, Giannotti L, Gnoni GV, Siculella L, Gnoni A. Quercetin inhibition of SREBPs and ChREBP expression results in reduced cholesterol and fatty acid synthesis in C6 glioma cells. Int J Biochem Cell Biol. 2019;117:105618. https://doi.org/10.1016/j.biocel.2019.105618

97. Aravindhan K, Webb CL, Jaye M, Ghosh A, Willette RN, DiNardo NJ, et al. Assessing the effects of LXR agonists on cellular cholesterol handling: a stable isotope tracer study. J Lipid Res. 2006;47(6): 1250-60. https://doi.org/10.1194/jlr.M500512-JLR200

98. Xu H, Zhou S, Tang Q, Xia H, Bi F. Cholesterol metabolism: New functions and therapeutic approaches in cancer. Biochim Biophys Acta Rev Cancer. 2020:188394. https://doi.org/10.1016/j. bbcan.2020.188394

99. Silvente-Poirot S, Poirot M. Cholesterol and Cancer, in the Balance. Science. 2014;343(6178):1445-6. https://doi.org/10.1126/science.1252787

100. Krieger M, Goldstein JL, Brown MS. Receptor-mediated uptake of low density lipoprotein reconstituted with 25-hydroxycholesteryl oleate suppresses 3-hydroxy-3-methylglutaryl-coenzyme A reductase and inhibits growth of human fibroblasts. Proc Natl Acad Sci.1978;75(10):5052-6. https://doi. org/10.1073/pnas.75.10.5052 
101. Chen HW, Kandutsch AA, Waymouth C. Inhibition of cell growth by oxygenated derivatives of cholesterol. Nature. 1974;251(5474):419-21. https://doi.org/10.1038/251419a0

102. Clarion L, Schindler M, de Weille J, Lolmède K, Laroche-Clary A, Uro-Coste E, et al. $7 \beta$-Hydroxycholesterol-induced energy stress leads to sequential opposing signaling responses and to death of c6 glioblastoma cells. Biochem Pharmacol. 2012;83(1):37-46. https://doi.org/10.1016/j. bcp.2011.09.022

103. de Weille J, Fabre C, Bakalara N. Oxysterols in cancer cell proliferation and death. Biochem Pharmacol. 2013;86(1):154-60. https://doi.org/10.1016/j.bcp.2013.02.029

104. Wang X, Li Y, Xia X, Zhang M, Ge C, Xia X, et al. Mutagenicity of 7-ketocholesterol in CHO cells: The role of lipid peroxidation. Toxicol. 2020;446:152587. https://doi.org/10.1016/j.tox.2020.152587

105. Kloudova A, Guengerich FP, Soucek P. The Role of Oxysterols in Human Cancer. Trends Endocrinol Metab. 2017;28(7):485-96. https://doi.org/10.1016/j.tem.2017.03.002

106. Mutemberezi V, Guillemot-Legris O, Muccioli GG. Oxysterols: From cholesterol metabolites to key mediators. Prog Lipid Res. 2016;64:152-69. https://doi.org/10.1016/j.plipres.2016.09.002

107. Silvente-Poirot S, Poirot M. Cholesterol epoxide hydrolase and cancer. Curr Opin Pharmacol. 2012;12(6):696-703. https://doi.org/10.1016/j.coph.2012.07.007

108. de Medina P, Paillasse MR, Segala G, Poirot M, Silvente-Poirot S. Identification and pharmacological characterization of cholesterol-5,6-epoxide hydrolase as a target for tamoxifen and AEBS ligands. Proc Natl Acad Sci. 2010;107(30):13520-5. https://doi.org/10.1073/pnas.1002922107

109. Kedjouar B, de Médina P, Oulad-Abdelghani M, Payré B, Silvente-Poirot S, Favre G, et al. Molecular Characterization of the Microsomal Tamoxifen Binding Site. J Biol Chem. 2004;279(32):34048-61. https://doi.org/10.1074/jbc.M405230200

110. Gylling H, Pyrhönen S, Mäntylä E, Mäenpää H, Kangas L, Miettinen TA. Tamoxifen and toremifene lower serum cholesterol by inhibition of delta 8-cholesterol conversion to lathosterol in women with breast cancer. JCO. 1995;13(12):2900-5. https://doi.org/10.1200/JCO.1995.13.12.2900

111. Poirot M, Silvente-Poirot S, Weichselbaum RR. Cholesterol metabolism and resistance to tamoxifen. Curr Opin Pharmacol. 2012;12(6):683-9. https://doi.org/10.1016/j.coph.2012.09.007

112. de Medina P, Payré B, Boubekeur N, Bertrand-Michel J, Tercé F, Silvente-Poirot S, et al. Ligands of the antiestrogen-binding site induce active cell death and autophagy in human breast cancer cells through the modulation of cholesterol metabolism. Cell Death Differ. 2009;16(10):1372-84. https:// doi.org/10.1038/cdd.2009.62

113. de Medina P, Paillasse MR, Ségala G, Khallouki F, Brillouet S, Dalenc F, et al. Importance of cholesterol and oxysterols metabolism in the pharmacology of tamoxifen and other AEBS ligands. Chem Phys Lipids. 2011;164(6):432-7. https://doi.org/10.1016/j.chemphyslip.2011.05.005

114. Leignadier J, Dalenc F, Poirot M, Silvente-Poirot S. Improving the efficacy of hormone therapy in breast cancer: The role of cholesterol metabolism in SERM-mediated autophagy, cell differentiation and death. Biochem Pharmacol. 2017;144:18-28. https://doi.org/10.1016/j.bcp.2017.06.120

115. Segala G, David M, de Medina P, Poirot MC, Serhan N, Vergez F, et al. Dendrogenin A drives LXR to trigger lethal autophagy in cancers. Nat Commun. 2017;8(1):1903. https://doi.org/10.1038/ s41467-017-01948-9

116. Hwang PL, Matin A. Interactions of sterols with antiestrogen-binding sites: structural requirements for high-affinity binding. J Lipid Res. 1989;30(2):239-45. https://doi.org/10.1016/ S0022-2275(20)38384-X

117. Gill S, Chow R, Brown A. Sterol regulators of cholesterol homeostasis and beyond: The oxysterol hypothesis revisited and revised. Prog Lipid Res. 2008;47(6):391-404. https://doi.org/10.1016/j. plipres.2008.04.002

118. Luo J, Yang H, Song B-L. Mechanisms and regulation of cholesterol homeostasis. Nat Rev Mol Cell Biol. 2020;21(4):225-45. https://doi.org/10.1038/s41580-019-0190-7

119. Santos CR, Schulze A. Lipid metabolism in cancer: Lipid metabolism in cancer. FEBS J. 2012;279(15):2610-23. https://doi.org/10.1111/j.1742-4658.2012.08644.x

120. Lin C-Y, Huo C, Kuo L-K, Hiipakka RA, Jones RB, Lin H-P, et al. Cholestane-3 $\beta$, 5 $\alpha$, 6 6 -triol Suppresses Proliferation, Migration, and Invasion of Human Prostate Cancer Cells. Culig Z, editor. PLoS ONE. 2013;8(6):e65734. https://doi.org/10.1371/journal.pone.0065734 
121. Christ M, Luu B, Mejia JE, Moosbrugger I, Bischoff P. Apoptosis induced by oxysterols in murine lymphoma cells and in normal thymocytes. Immunol. 1993;78(3):455.

122. Aupeix K, Weltin D, Mejia JE, Christ M, Marchal J, Freyssinet J-M, et al. Oxysterol-induced Apoptosis in Human Monocytic Cell Lines. Immunobiol. 1995;194(4-5):415-28. https://doi.org/10.1016/ S0171-2985(11)80108-7

123. Lizard G, Monier S, Cordelet C, Gesquiere L, Deckert V, Gueldry S, et al. Characterization and comparison of the mode of cell death, apoptosis versus necrosis, induced by $7 \beta$-hydroxycholesterol and 7-ketocholesterol in the cells of the vascular wall. Arterioscler Thromb Vasc Biol. 1999;19(5): 1190-200. https://doi.org/10.1161/01.ATV.19.5.1190

124. Ryan L, O'Callaghan YC, O'Brien NM. Comparison of the apoptotic processes induced by the oxys-

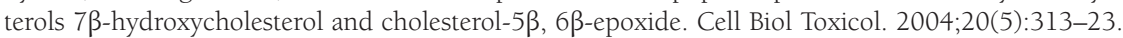
https://doi.org/10.1007/s10565-004-5066-7

125. O'callaghan Y, Woods JA, O'brien N. Comparative study of the cytotoxicity and apoptosis-inducing potential of commonly occurring oxysterols. Cell Biol Toxicol. 2001;17(2):127-37. https://doi. org/10.1023/A:1010914306375

126. Bansal N, Houle A, Melnykovych G. Apoptosis: mode of cell death induced in T cell leukemia lines by dexamethasone and other agents. FASEB J. 1991;5(2):211-6. https://doi.org/10.1096/ fasebj.5.2.2004665

127. Christ M, Ji YH, Moog C, Pannecoucke X, Schmitt G, Bischoff P, et al. Antitumor activity of oxysterols. Effect of two water-soluble monophosphoric acid diesters of 7 beta-hydroxycholesterol on mastocytoma P815 in vivo. Anticancer Res. 1991;11(1):359-64.

128. Vejux A, Abed-Vieillard D, Hajji K, Zarrouk A, Mackrill JJ, Ghosh S, et al. 7-Ketocholesterol and $7 \beta$-hydroxycholesterol: In vitro and animal models used to characterize their activities and to identify molecules preventing their toxicity. Biochem Pharmacol. 2020;173:113648. https://doi.org/10.1016/j. bcp. 2019.113648

129. Kiechle FL, Zhang X. Apoptosis: biochemical aspects and clinical implications. Clinica Chimica Acta. 2002;326(1-2):27-45. https://doi.org/10.1016/S0009-8981(02)00297-8

130. Ashe PC, Berry MD. Apoptotic signaling cascades. Prog Neuropsychopharmacol Biol Psychiatry. 2003;27(2):199-214. https://doi.org/10.1016/S0278-5846(03)00016-2

131. Cain K, Bratton SB, Cohen GM. The Apaf-1 apoptosome: a large caspase-activating complex. Biochimie. 2002;84(2-3):203-14. https://doi.org/10.1016/S0300-9084(02)01376-7

132. Thorburn A. Death receptor-induced cell killing. Cell Signal. 2004;16(2):139-44. https://doi. org/10.1016/j.cellsig.2003.08.007

133. McDonnell DP, Park S, Goulet MT, Jasper J, Wardell SE, Chang C -y, et al. Obesity, Cholesterol Metabolism, and Breast Cancer Pathogenesis. Cancer Res. 2014;74(18):4976-82. https://doi. org/10.1158/0008-5472.CAN-14-1756

134. Rakotoarivelo C, Adamczyk M, Desgeorges M, Langley K, Lorentz JG, Mann A, et al. $7 \beta$-Hydroxycholesterol blocked at C-3-OH inhibits growth of rat glioblastoma in vivo: Comparison between $7 \beta$-hydroxycholesteryl-3 $\beta$ (ester)-oleate and $7 \beta$-hydroxycholesteryl-3 $\beta-O$ (ether)-oleyl. Anticancer Res. 2006;26(3A):2053-62.

135. O'callaghan YC, Woods JA, O'brien NM. Characteristics of $7 \beta$-hydroxycholesterol-induced cell death in a human monocytic blood cell line, U937, and a human hepatoma cell line, HepG2. Toxicol In Vitro. 2002;16(3):245-51. https://doi.org/10.1016/S0278-6915(02)00050-9

136. Panini SR, Sinensky MS. Mechanisms of oxysterol-induced apoptosis. Curr Opin Lipidol. 2001;12(5):529-33. https://doi.org/10.1097/00041433-200110000-00008

137. Miguet-Alfonsi C, Prunet C, Monier S, Bessède G, Lemaire-Ewing S, Berthier A, et al. Analysis of oxidative processes and of myelin figures formation before and after the loss of mitochondrial transmembrane potential during 7 7 -hydroxycholesterol and 7-ketocholesterol-induced apoptosis: comparison with various pro-apoptotic chemicals. Biochem Pharmacol. 2002;64(3):527-41. https://doi. org/10.1016/S0006-2952(02)01110-3

138. Ryan L, O'Callaghan YC, O'Brien NM. Generation of an oxidative stress precedes caspase activation during 7ß-hydroxycholesterol-induced apoptosis in U937 cells. J Biochem Mol Toxicol. 2004;18(1):50-9. https://doi.org/10.1002/jbt.20007 
139. Roussi S, Gossé F, Aoudé-Werner D, Zhang X, Marchioni E, Geoffroy P, et al. Mitochondrial perturbation, oxidative stress and lysosomal destabilization are involved in $7 \beta$-hydroxysitosterol and $7 \beta$-hydroxycholesterol triggered apoptosis in human colon cancer cells. Apoptosis. 2007;12(1): 87-96. https://doi.org/10.1007/s10495-006-0485-y

140. Nury T, Zarrouk A, Yammine A, Mackrill JJ, Vejux A, Lizard G. Oxiapoptophagy: A type of cell death induced by some oxysterols. Br J Pharmacol. 2020: 1-9. https://doi.org/10.1111/bph.15173

141. Doblas S, He T, Saunders D, Pearson J, Hoyle J, Smith N, et al. Glioma morphology and tumorinduced vascular alterations revealed in seven rodent glioma models by in vivo magnetic resonance imaging and angiography. J Magn Reson Imaging. 2010;32(2):267-75. https://doi.org/10.1002/ jmri.22263

142. Doblas S, He T, Saunders D, Hoyle J, Smith N, Pye Q, et al. In vivo characterization of several rodent glioma models by 1H MRS: MRS IN VARIOUS RODENT GLIOMAS. NMR Biomed. 2012;25(4): 685-94. https://doi.org/10.1002/nbm.1785

143. Giakoumettis D, Kritis A, Foroglou N. C6 cell line: the gold standard in glioma research. Hippokratia. 2018;22(3):105.

144. Shen G, Shen F, Shi Z, Liu W, Hu W, Zheng X, et al. Identification of cancer stem-like cells in the C6 glioma cell line and the limitation of current identification methods. In Vitro CellDevBiol-Animal. 2008;44(7):280-9. https://doi.org/10.1007/s11626-008-9115-z

145. Karmakar S, Foster Olive M, Banik NL, Ray SK. Intracranial Stereotaxic Cannulation for Development of Orthotopic Glioblastoma Allograft in Sprague-Dawley Rats and Histoimmunopathological Characterization of the Brain Tumor. Neurochem Res. 2007;32(12):2235-42. https://doi.org/10.1007/ sl1064-007-9450-6

146. Samadi M, Nury T, Khalafi-Nezhad A, Lizard G. Protecting group-free radical decarboxylation of bile acids: Synthesis of novel steroidal substituted maleic anhydrides and maleimides and evaluation of their cytotoxicity on C6 rat glioma cells. Steroids. 2017;125:124-30. https://doi.org/10.1016/j. steroids.2017.07.004

147. Sassi K, Nury T, Zarrouk A, Sghaier R, Khalafi-Nezhad A, Vejux A, et al. Induction of a non-apoptotic mode of cell death associated with autophagic characteristics with steroidal maleic anhydrides and 7ß-hydroxycholesterol on glioma cells. J Steroid Biochem Mol Biol. 2019;191:105371. https://doi. org/10.1016/j.jsbmb.2019.04.020

148. Guntuku L, Naidu VGM, Ganesh Yerra V. Mitochondrial Dysfunction in Gliomas: Pharmacotherapeutic Potential of Natural Compounds. Curr Neuropharmacol. 2016;14(6):567-83. https://doi.org/10.2174/ 1570159X14666160121115641

149. Elustondo P, Martin LA, Karten B. Mitochondrial cholesterol import. Biochim Biophys Acta Mol Cell Biol Lipids. 2017;1862(1):90-101. https://doi.org/10.1016/j.bbalip.2016.08.012

150. Gogvadze V, Orrenius S, Zhivotovsky B. Mitochondria as targets for chemotherapy. Apoptosis. 2009;14(4):624-40. https://doi.org/10.1007/s10495-009-0323-0

151. Katsetos CD, Anni H, Dráber P. Mitochondrial Dysfunction in Gliomas. Seminars in Pediatric Neurol. 2013;20(3):216-27. https://doi.org/10.1016/j.spen.2013.09.003

152. Sutendra G, Michelakis ED. Pyruvate dehydrogenase kinase as a novel therapeutic target in oncology. Front Oncol. 2013;3:38. https://doi.org/10.3389/fonc.2013.00038

153. Michelakis ED, Sutendra G, Dromparis P, Webster L, Haromy A, Niven E, et al. Metabolic Modulation of Glioblastoma with Dichloroacetate. Sci Transl Med. 20102;2(31):31ra34. https://doi.org/10.1126/ scitranslmed. 3000677

154. Jeon S-H, Kim SH, Kim Y, Kim YS, Lim Y, Lee YH, et al. The tricyclic antidepressant imipramine induces autophagic cell death in U-87MG glioma cells. Biochem Biophys Res Commun. 2011;413(2):311-7. https://doi.org/10.1016/j.bbrc.2011.08.093

155. Lv L, Zheng L, Dong D, Xu L, Yin L, Xu Y, et al. Dioscin, a natural steroid saponin, induces apoptosis and DNA damage through reactive oxygen species: A potential new drug for treatment of glioblastoma multiforme. Food Chem Toxicol. 2013;59:657-69. https://doi.org/10.1016/j.fct.2013.07.012

156. Hanahan D, Weinberg RA. The hallmarks of cancer. Cell. 2000;100(1):57-70. https://doi.org/10.1016/ S0092-8674(00)81683-9 
157. Werner H, Le Roith D. New concepts in regulation and function of the insulin-like growth factors: implications for understanding normal growth and neoplasia. Cell Mol Life Sci. 2000;57(6):932-42. https://doi.org/10.1007/PL00000735

158. Zhao Q, Jiang Y, Zhang M, Chu Y, Ji B, Pan H, et al. Low-density lipoprotein cholesterol levels are associated with insulin-like growth factor-1 in short-stature children and adolescents: a cross-sectional study. Lipids Health Dis. 2019;18(1):120. https://doi.org/10.1186/s12944-019-1062-z

159. Prewitt TE, Unterman TG, Glick R, Cole TG, Schmeisser D, Bowen PE, et al. Insulin-like growth factor I and low-density-lipoprotein cholesterol in women during high- and low-fat feeding. Am J Clin Nutr. 1992;55(2):381-4. https://doi.org/10.1093/ajcn/55.2.381

160. Weiss B, Davidkova G, Zhou L-W. Antisense RNA gene therapy for studying and modulating biological processes. Cell Mol Life Sci. 1999;55(3):334-58. https://doi.org/10.1007/s000180050296

161. Myers KJ, Dean NM. Sensible use of antisense: how to use oligonucleotides as research tools. Trends Pharmacol Sci. 2000;21(1):19-23. https://doi.org/10.1016/S0165-6147(99)01420-0

162. Resnicoff M, Sell C, Rubini M, Coppola D, Ambrose D, Baserga R, Rubin R. Rat glioblastoma cells expressing an antisense RNA to the insulin-like growth factor-1 (IGF-1) receptor are nontumorigenic and induce regression of wild-type tumors. Cancer Res. 1994;54(8):2218-22.

163. Resnicoff M. Antitumor effects elicited by antisense-mediated downregulation of the insulin-like growth factor I receptor. Int J Mol Med. 1998;1(5):883-91. https://doi.org/10.3892/ijmm.1.5.883

164. Alphandéry. Nano-Therapies for Glioblastoma Treatment. Cancers. 2020;12(1):242. https://doi. org/10.3390/cancers 12010242

165. Ediriwickrema A, Saltzman WM. Nanotherapy for Cancer: Targeting and Multifunctionality in the Future of Cancer Therapies. ACS Biomater Sci Eng. 2015;1(2):64-78. https://doi.org/10.1021/ ab500084g

166. Hadjipanayis CG, Machaidze R, Kaluzova M, Wang L, Schuette AJ, Chen H, Wu X, Mao H. EGFRvIII antibody conjugated iron oxide nanoparticles for MRI guided convection-enhanced delivery and targeted therapy of glioblastoma. Cancer Res. 2010;70(15):6303. https://doi.org/10.1158/0008-5472. CAN-10-1022

167. Mirjolet C, Papa AL, Créhange G, Raguin O, Seignez C, Paul C, et al. The radiosensitization effect of titanate nanotubes as a new tool in radiation therapy for glioblastoma: A proof-of-concept. Radiother Oncol. 2013;108(1):136-42. https://doi.org/10.1016/j.radonc.2013.04.004

168. Maier-Hauff K, Ulrich F, Nestler D, Niehoff H, Wust P, Thiesen B, et al. Efficacy and safety of intratumoral thermotherapy using magnetic iron-oxide nanoparticles combined with external beam radiotherapy on patients with recurrent glioblastoma multiforme. J Neurooncol. 2011;103(2):317-24. https://doi.org/10.1007/s11060-010-0389-0

169. Favero GM, Paz JL, Otake AH, Maria DA, Caldini EG, de Medeiros RSS, et al. Cell internalization of 7-ketocholesterol-containing nanoemulsion through LDL receptor reduces melanoma growth in vitro and in vivo : a preliminary report. Oncotarget. 2018;9(18):14160-74. https://doi.org/10.18632/ oncotarget. 24389

170. Traversari C, Sozzani S, Steffensen KR, Russo V. LXR-dependent and -independent effects of oxysterols on immunity and tumor growth: Highlights. Eur J Immunol. 2014;44(7):1896-903. https://doi. org/10.1002/eji.201344292

171. Traversari C, Russo V. Control of the immune system by oxysterols and cancer development. Curr Opin Pharmacol. 2012;12(6):729-35. https://doi.org/10.1016/j.coph.2012.07.003

172. Bischoff P, Holl V, Coelho D, Dufour P, Luu B, Weltin D. Apoptosis at the Interface of Immunosuppressive and Anticancer Activities: The Examples of Two Classes of Chemical Inducers, Oxysterols and Alkylating Agents. Curr Med Chem. 2000;7(7):693-713. https://doi.org/10.2174/0929867003374769 
